\title{
Calcium sensing receptor form s complex with and is up-regulated by caveolin-1 in cultured human osteosarcoma (Saos-2) cells
}

\author{
Sang Yong Jung ${ }^{1 *}$, Jin-Oh Kwak ${ }^{2 *}$, \\ Hyun-Woo Kim ${ }^{2}$, Dong Su Kim ${ }^{3}$, \\ Seung-Duk Ryu ${ }^{2}$, Chang-Bo Ko ${ }^{4}$ \\ and Seok Ho $\mathrm{Cha}^{2,5,6}$ \\ ${ }^{1}$ Department of Physiology and Biophysics \\ ${ }^{2}$ Department of Pharmacology and Toxicology \\ ${ }^{3}$ Department of Dentistry \\ College of Medicine Inha University \\ Incheon, Korea \\ ${ }^{4}$ Hormone Research Center \\ School of Biological Sciences and Technology \\ Chonnam National University \\ 300 Yongbong-dong, Buk-gu \\ Gwangju 500-757, Korea \\ ${ }^{5}$ Kidney Disease Research Group in Inha \\ Research Institute for Medical Sciences \\ ${ }^{6}$ Corresponding author: Tel, 82-32-890-0957; \\ Fax, 82-32-890-0957; E-mail, shcha@inha.ac.kr \\ ${ }^{*}$ Theses authors contributed equally to this work.
}

Accepted 24 February 2005

Abbreviations: CaSR, calcium sensing receptor; Cav-1, Caveolin-1; $\left[\mathrm{Ca}^{2+}\right]_{\mathrm{i}}$, Intracellular calcium concentration; $\left[\mathrm{Ca}^{2+}\right]_{0}$, Extracellular calcium concentration; FITC, Fluorescein isothiocyanate; ODN, antisense oligodeoxynucleotide, PLC, phospholipase C; Saos-2, osteosarcoma cell line

\footnotetext{
Abstract

The calcium sensing receptor ( $C a S R$ ) plays an important role for sensing local changes in the extracellular calcium concentration $\left(\left[\mathrm{Ca}^{2+}\right]_{0}\right)$ in bone remodeling. Although the function of $\mathrm{CaSR}$ is known, the regulatory mechanism of CaSR remains controversial. We report here the regulatory effect of caveolin on CaSR function as a process of CaSR regulation by using the human osteosarcoma cell line (Saos-2). The intracellular calcium concentration $\left(\left[\mathrm{Ca}^{2+}\right]_{i}\right)$ was increased by an increment of $\left[\mathrm{Ca}^{2+}\right]_{0}$. This $\left[\mathrm{Ca}^{2+}\right]_{i}$ increment was inhibited by the pretreatment with NPS 2390, an antagonist of CaSR. RT-PCR and Western blot analysis of Saos-2 cells revealed
}

the presence of CaSR, caveolin ( $\mathrm{Cav}$ )-1 and -2 in both mRNA and protein expressions, but there was no expression of Cav-3 mRNA and prote in in the cells. In the isolated caveolae-rich membrane fraction from Saos-2 cells, the CaSR, Cav-1 and Cav-2 proteins were localized in same fractions (fraction number 4 and 5). The immunoprecipitation experiment using the respective antibodies showed complex formation between the CaSR and Cav-1, but no complex formation of CaSR and Cav-2. Confocal microscopy also supported the co-localization of CaSR and Cav-1 at the plasma membrane. Functionally, the $\left[\mathrm{Ca}^{2+}\right]_{0^{-}}$ induced $\left[\mathrm{Ca}^{2+}\right]_{i}$ increment was attenuated by the introduction of Cav-1 antisense oligodeoxynucleotide (ODN). From these results, in Saos-2 cells, the function of CaSR might be regulated by binding with Cav-1. Considering the decrement of CaSR activity by antisense ODN, Cav-1 up-regulates the function of CaSR under normal physiological conditions, and it may play an important role in the diverse pathophysiological processes of bone remodeling or in the CaSR. related disorders in the body.

Keywords: antisense oligodeoxynucleotides; calcium sensing receptor; caveolae; caveolin-1; confocal microscopy; osteosarcoma cell line

\section{Introduction}

Extracellular calcium is essential for a number of vital processes, including bone mineralization, blood coagulation, regulation of enzymatic activity, and the modulation of permeability and excitability of the plasma membranes. For these reasons, the calcium concentration in extracellular fluids is under strict control by a complex homeostatic system that includes the bones, kidney, intestines, parathyroid and thyroid glands (Brown, 1991). The extracellular calcium sensing receptor (CaSR) is an essential component of this system for regulating parathyroid hormone secretion, $\mathrm{Ca}^{2+}$ excretion by the kidney and bone remodeling. The CaSR belongs to the type III family of G-proteincoupled receptors, which comprises the metabotropic glutamate receptor and putative vomeronasal organ receptors (Brown et al., 1993). Several lines of evidence have suggested that an increase in local 
calcium concentration in the resorption lacunae suppresses osteoclastic bone-resorbing activity through an increase in intracellular calcium; this is mediated through a ryanodine-like receptor (Zaidi et al., 1989; 1991; 1993; Adebanjo et al., 1994; Shin et al., 2003) and the CaSR regulates osteoclastic bone resorption (Kameda et al., 1998).

Caveolae are plasma membrane organelles that are characterized by a low solubility in Triton X-100 and these are the organelles where specific lipid and protein components are subcompartmentalized (Kurzchalia and Parton, 1999). Caveolin (Cav), a 21- to $24-\mathrm{kDa}$ integral membrane protein, is a principal component of the caveolae membrane and it exists as several isoforms (Cav-1, -2, and -3) (Okamoto et al., 1998; Kurzchalia and Parton, 1999). Recent studies have shown that functional proteins including receptors are localized in the caveolae by being anchored through the caveolins (Li et al., 1995; GarciaCardena et al., 1996; Couet et al., 1997; Lee et al., 2001; Cha et al., 2004). In bone, there is no evidence of the interaction between caveolin and $\mathrm{CaSR}$, and for the regulatory effect of caveolin on CaSR function.

The purpose of present study, therefore, is to demonstrate the relationship between CaSR and caveolins in the osteosarcoma cell line (Saos-2). Our results show that CaSR protein is co-localized together with Cav-1 in the caveolae-rich membrane fractions. Immuno-cytochemical confocal microscopic examinations supported that CaSR is co-localized with Cav-1 in the plasma membrane of Saos-2 cells.

\section{Materials and Methods}

\section{Materials}

The materials used in the present study were purchased from following sources: TRI Reagent and chemicals used in this experiment from Sigma chemical (St. Louis, MO), Reverse transcription-polymerase chain reaction (RT-PCR) related materials from TaKaRa Korea Biomedical Co (Seoul, Korea), materials for cell culture from Gibco BRL (Grand Island, NY), Fura-2/ AM from Molecular Probe (Oregon), Polyclonal rabbit anti-rat CaSR from Affinity BioReagents (Deerfield, IL), monoclonal Cav-1, -2 and -3 antibodies from Transduction Laboratories (Lexington, MS), scrambled and antisense oligodeoxynucleotides from GenoTech Corp. (Taejeon, Korea), TA-cloning vector was from Invitrogen Co. (Carlsbad, CA) and secondary antibodies were from Jackson Immunoresearch (West Grove, PA).

\section{Cell culture}

Saos-2 cell line (ATCC number HBT-85) was purchased from American Type Culture Collection. Cells were incubated in a humidified atmosphere of $5 \%$ $\mathrm{CO}_{2}$ in air at $37^{\circ} \mathrm{C}$. Basal medium was DMEM supplemented with $10 \%$ FBS, $100 \mathrm{U} / \mathrm{ml}$ penicillin G sodium and $100 \mu \mathrm{g} / \mathrm{ml}$ streptomycin.

\section{Measurement of $\left[\mathrm{Ca}^{2+}\right]_{i}$}

$\left[\mathrm{Ca}^{2+}\right]_{i}$ was measured using the method previously described (Cha et al., 2000; Rasheed and Saeed, 2004). Cells were harvested and seeded on to a 22 $\times 22$ cover glass at a concentration of $10^{4}$ cells/dish on the two days before conducting the experiment. The cover glass was attached to a $1-\mathrm{cm}^{2}$ area at the bottom of $35-\mathrm{mm}$ plastic culture dishes. Cells were then washed with modified Hanks' solution consisting of (in $\mathrm{mM}): \mathrm{NaCl}, 127 ; \mathrm{MgSO}_{4}, 0.8 ; \mathrm{KH}_{2} \mathrm{PO}_{4}, 0.44 ; \mathrm{NaHPO}_{4}$, $0.33 ; \mathrm{MgCl}_{2}$, 1 ; HEPES, $10 ; \mathrm{CaCl}_{2}, 0.5, \mathrm{pH}$ 7.4. The cells were then loaded in fura-2/AM $(10 \mu \mathrm{M})$ for 30 $\min$ at $37^{\circ} \mathrm{C}$. Fluorescence-loaded cells were washed three times with the same solution to exclude the unloaded fura-2/AM. The fluorescence in Saos-2 cells was measured at room temperature using the $\mathrm{InCa}^{\mathrm{TM}}$ Imaging System (Intracellular Imaging Inc., Cincinnati, Ohio). The $\left[\mathrm{Ca}^{2+}\right]$ i was calculated from a standard curve generated in situ. Following scrambled and antisense oligodeoxynucleotide (ODN) sequences were used; scrambled ODN, 5'-CTCGATCCTGACTACTG-3'; Cav1 antisense ODN, ATGTCCCTCCGAGTCTA- 3' (Griffoni et al., 2000).

\section{$R T-P C R$ analysis}

The RT-PCR was performed using total RNA (500 ng) by using TRI Reagent sigma-Aldrich (St. Louis, MO). RNA was reverse transcribed using $5 \mathrm{U}$ of AMV reverse transcriptase $\mathrm{XL}$ for $30 \mathrm{~min}$. The prepared CDNAs were employed as template for PCR and the condition for PCR was as follows; one cycle of $1 \mathrm{~min}$ at $94^{\circ} \mathrm{C}, 35$ cycles each for $30 \mathrm{~s}$ at $94^{\circ} \mathrm{C}, 30 \mathrm{~s}$ at $55^{\circ} \mathrm{C}$ and $90 \mathrm{~s}$ at $72^{\circ} \mathrm{C}$, and one final cycle of 10 $\min$ at $72^{\circ} \mathrm{C}$. The sets of primers used in this experiment for PCR amplification were as follows: CaSR, sense 5'-TCAACCTGCAGTTCCTGCTGG-3' and antisense 5'-TGGCATAGGCTGGAATGAAGG-3' (product size 318 bp); Cav-1, sense 5'-TCTACAAGCCCAACAACAAGGCC-3' and antisense 5'-TGCACTGAATCTCAATCAGGAAGC-3' (product size 360 bp); Cav-2, sense 5'-ATGGGGCTGGAGACGGAGAAGG-3' and antisense 5'-ATCCAGATGTGCAGACAGCTGAGG-3' (product size $341 \mathrm{bp}$ ); Cav-3, sense 5'-TCAAGGATATCCACTGCAAGG-3' and antisense 5'-AAGAGTGGGTTGCAGAAGGTGC-3' (product size 359 bp). The PCR products $(15 \mu \mathrm{l})$ were then separated in a $1 \%$ agarose gel electrophoresis and stained with ethidium bromide.

\section{Western blot analysis}

The Saos-2 cells were washed with cold phosphatebuffered saline (PBS, pH 7.4) and harvested. Subsequently, the cells were homogenized in 9 volumes of $0.3 \mathrm{M}$ sucrose, $0.26 \mathrm{U} / \mathrm{ml}$ aprotinin, $0.1 \mathrm{mM}$ phenylmethylsulfonyl fluoride, $10 \mu \mathrm{g} / \mathrm{ml}$ leupeptin, and $10 \mu \mathrm{g} /$ $\mathrm{ml}$ trypsin inhibitor, with 10 strokes of a motor-driven Teflon/glass hemogenizer. The homogenate was centrifuged for $10 \mathrm{~min}$ at $8,000 \mathrm{rpm}$, and the supernatant was centrifuged further for $20 \mathrm{~min}$ at $8,000 \mathrm{rpm}$. The supernatant was centrifuged for $40 \mathrm{~min}$ at 45,000 
rpm, and the membrane pellet was re-suspended in $0.25 \mathrm{M}$ sucrose, $100 \mathrm{mM} \mathrm{KCl}, 5 \mathrm{mM} \mathrm{MgCl}_{2}$, and 50 $\mathrm{mM}$ Tris ( $\mathrm{pH}$ 7.4). The protein samples were heated at $100^{\circ} \mathrm{C}$ for $10 \mathrm{~min}$ in sample buffer and subjected to $10 \%$ SDS-polyacrylamide gel electrophoresis. The separated proteins were transferred electrically to a Hybond-P polyvinylidene difluoride transfer membrane (Amersham Pharmacia Biotech). This membrane was blocked with solution of $5 \%$ non-fat dried milk. Membrane was then incubated with CaSR antibody (1: $200)$, caveolin antibodies $(1: 200)$ for $1 \mathrm{~h}$ at room temperature and then incubated further with the horseradish peroxidase-conjugated secondary antibody $(1: 3,000)$ for another $1 \mathrm{~h}$ at room temperature. After washing, the membrane was visualized by the $E C L$ kit (Amersham Pharmacia Biotech. Buckinghamshire, UK).

\section{Preparation of caveolae-enriched membrane fractionation}

Caveolae-rich membrane fraction from Saos-2 cells was fractionated using sucrose gradient ultracentrifugation (Liou et al., 2001). In brief, Saos-2 cells were homogenized in $2 \mathrm{ml}$ of lysis buffer $(10 \mathrm{mM}$ Tris-HCL, $\mathrm{pH} 7.5,150 \mathrm{mM} \mathrm{NaCl}, 5 \mathrm{mM}$ EDTA, $1 \mathrm{mM}$ phenylmethylsulfonyl fluoride, $10 \mu \mathrm{g} / \mathrm{ml}$ leupeptin, $10 \mu \mathrm{g} / \mathrm{ml}$ trypsin inhibitor, and $1 \%$ Triton $\mathrm{X}-100$ ) followed by sonication. The homogenate was brought to $40 \%$ sucrose by addition of an equal volume of $80 \%$ sucrose and loaded in an ultracentrifuge tube. A discontinuous sucrose gradient was layered on top of the sample by placing $4 \mathrm{ml}$ of $30 \%$ and $4 \mathrm{ml}$ of $5 \%$ sucrose, respectively. After centrifugation at 200,000 $\times \mathrm{g}$ for $16-20 \mathrm{~h}$ at $4^{\circ} \mathrm{C}$, the twelve $1-\mathrm{ml}$ fractions from the top to the bottom were collected. Each fraction was analyzed by Western blot for its CaSR and Cav-1 using specific antibodies, respectively.

\section{Imm uno-precipitation}

The lysates of Saos-2 cells were incubated with antibodies specific for CaSR, Cav-1, and Cav-2 or a pre-immune rabbit or mouse $\lg G$ at a final concentration of $4 \mu \mathrm{g} / \mathrm{ml}$ for $4 \mathrm{~h}$ at $4^{\circ} \mathrm{C}$. Protein-A-Sepharose was then added for $2 \mathrm{~h}$ at $4^{\circ} \mathrm{C}$. Thereafter, the samples were centrifuged and the pellets were washed 4 times with RIPA buffer $(150 \mathrm{mM} \mathrm{NaCl}, 1 \mathrm{mM}$ EDTA, $1 \%$ triton $\mathrm{X}-100,1 \% \mathrm{NP}-40,0.05 \% \mathrm{SDS}$, and $10 \mathrm{mM}$ Tris; $\mathrm{pH} 8.0$ ) and then prepared for the Western blot analysis by boiling in the sample buffer to determine whether interactive binding has occurred between CaSR and caveolins.

\section{Confocal microscopy}

The cultured Saos-2 cells on cover slips were fixed with $95 \%$ ice-cold ethanol for $10 \mathrm{~min}$ at room temperature and permeabilized by $0.1 \%$ Triton $\mathrm{X}-100$ solution in PBS (10 $\mathrm{min}$, room temperature). The nonspecific binding sites were blocked with $10 \%$ goat serum in PBS for $30 \mathrm{~min}$ in room temperature.
Polyclonal CaSR antibodies (1:200), and Cav-1 (1:50) were treated to the fixed cells for $1 \mathrm{~h}$ in room temperature. Secondary antibodies without prior antibody treatment were also included as controls. After washing, cells were double stained with FITC- and Texas Red-conjugated secondary antibodies for $30 \mathrm{~min}$. After washing, samples were examined both at the green- and red-wavelengths under a Bio-Rad MRC 1,000 confocal microscope. More than 50 cells have been inspected per experiment and the photos of cells with typical morphology and staining are presented.

\section{Statistical analysis}

Statistical analyses were performed using the ANOVA test for multiple comparison and a $P$ value $<0.05$ was considered significantly different.

\section{Results}

\section{Expression of CaSR and caveolins in Saos-2 cells}

In order to identify levels of CaSR and caveolins (mRNAs and proteins) within Saos-2 cells, RT-PCR and Western blot analysis were performed. As shown in Figure 1A, the expressions of Cav-1 and Cav-2 mRNA in the Saos-2 cells were observed at almost the same degree. The expression of CaSR mRNA was also detected. As shown in Figure 1B, protein expressions of CaSR, Cav-1 and Cav-2 were observed. The Saos-2 cells did not express mRNA or the protein of Cav-3 (Figure $1 \mathrm{~A}$ and $1 \mathrm{~B}$ ). The identities of PCR product were confirmed by nucleotide sequencing after subcloning to TA-cloning vector (data not shown).

In order to functionally demonstrate the existence of CaSR in Saos-2 cells, the $\left[\mathrm{Ca}^{2+}\right]_{i}$ increment by increment of the extracellular calcium concentration was measured. When $\left[\mathrm{Ca}^{2+}\right]_{0}$ was changed from 0.5 $\mathrm{mM}$ to 5 and $10 \mathrm{mM}$, the $\left[\mathrm{Ca}^{2+}\right]_{0}$-mediated $\left[\mathrm{Ca}^{2+}\right]_{i}$ was increased in a concentration-dependent manner. The basal level of $\left[\mathrm{Ca}^{2+}\right]_{i}$ was $83.2 \pm 6.1 \mathrm{nM}$ and peak values of $\left[\mathrm{Ca}^{2+}\right]_{\mathrm{i}}$ were $195.6 \pm 10.3 \mathrm{nM}\left(\left[\mathrm{Ca}^{2+}\right]_{0}=5\right.$ $\mathrm{mM})$ and $289.3 \pm 9.6 \mathrm{nM}\left(\left[\mathrm{Ca}^{2+}\right]_{0}=10 \mathrm{mM}\right)$. As shown in Figure $1 \mathrm{C}$, fura 2 fluorescence showed a transient increase to a peak within $1 \mathrm{~min}$ after adding extracellular calcium and the fura 2 fluorescence decreased until a steady level was reached at between $90-150 \mathrm{~s}$ after the peak. This $\left[\mathrm{Ca}^{2+}\right]_{0}$-stimulated $\left[\mathrm{Ca}^{2+}\right]_{\mathrm{i}}$ increment was significantly attenuated in a concentration-dependent manner $(1$ and $10 \mu \mathrm{M})$ by the pretreatment for $2 \mathrm{~min}$ with NPS 2390 (Figure 1C), which is an antagonist of CaSR.

\section{Co-localization of $\mathrm{CaSR}$ and caveolins in the caveolae-rich membrane fraction or co-precipitates by their antibodies}

Figure $2 \mathrm{~A}$ shows the results of Western blot analysis using the antibodies of CaSR, Cav-1, Cav-2 or Cav-3 
$\Delta$
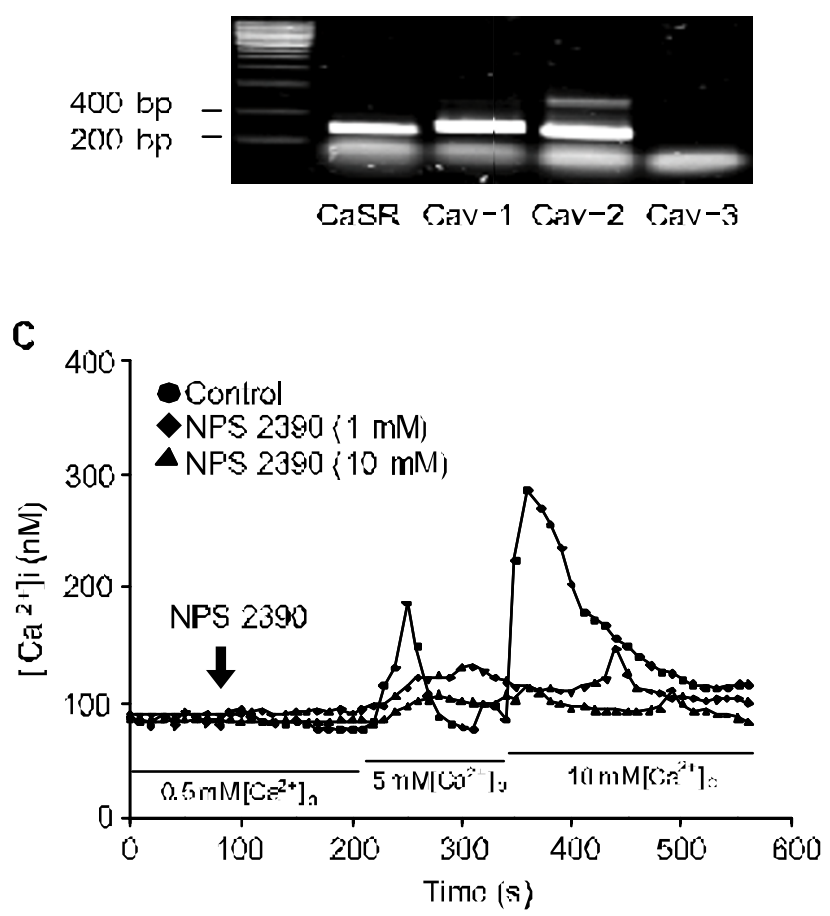

on the caveolae-enriched membranous fractions obtained from the sucrose density gradient centrifugations of Saos-2 cells. In the membrane fractions of Saos-2 cells, both Cav-1 and Cav-2 proteins were observed mainly in the fractions number 4 and 5 . In these fractions, Cav-3 protein was not observed (Figure 2A). In addition, CaSR protein was observed along with Cav-1 and Cav-2 in the same fractions numbered 4 and 5 (Figure $2 \mathrm{~A}$ ).

To determine whether there is a direct binding between the CaSR and caveolins, the cell lysates of Saos-2 were initially immuno-precipitated with the antibodies directed against CaSR, Cav-1 or Cav-2. Subsequently, the obtained precipitates were electrophoresed by SDS-PAGE and the separated proteins were electrically transferred to a membrane. The formations of complexes between the CaSR and Cavs were analyzed by Western blot analysis using designated antibodies. The CaSR or Cav-1 proteins did not precipitate with the control IgG (Figure 2B and $2 \mathrm{C}$, designated none). As shown in Figure 2B, the presence of CaSR and Cav-1 complex was detected upon precipitation with CaSR antibody (left panel of Figure 2B). The presence of CaSR and Cav-1 complex could also be detected following precipitation with Cav-1 antibody (right panel of Figure 2B). Although Cav-2 protein was co-localized in the same fractions with the CaSR protein, formation of CaSR and Cav-2 complex was not detected (Figure 2C).
B

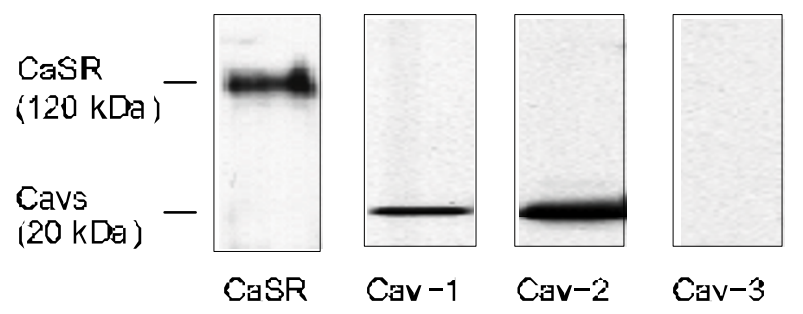

Figure 1. Expression of CaSR and Caveolins (mRNAs and proteins), determination of $\left[\mathrm{Ca}^{2+}\right]_{0}$-mediated $\left[\mathrm{Ca}^{2+}\right]_{i}$ increment and antagonistic

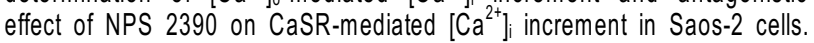
(A) Messenger RNA expression of CaSR and caveolins in Saos-2 cells. Total RNA $(500 \mathrm{ng})$ isolated from Saos-2 cells was reverse transcribed and polymerase chain reaction was performed 35 cycles. PCR products were separated using $1 \%$ agarose gel and stained with ethidium bromide. (B) Isolated membrane protein ( $30 \mu \mathrm{g} / \mathrm{lane}$ ) was separated by electrophoresis and presence of each CaSR and caveolins were detected with respective antibodies. Data was shown typical result from three independent experiments. (C) Cells were loaded in fura-2/AM (10 $\mu \mathrm{M})$ for $30 \mathrm{~min}$ at $37^{\circ} \mathrm{C}$. Fluorescence-loaded cells were washed three times with the same solution to exclude the unloaded fura-2/AM. The fluorescence in Saos-2 cells was measured at room temperature using the $\mathrm{InCa}^{\mathrm{TM}}$ Imaging System. Calcium concentration of extracellular milieu was changed from $0.5 \mathrm{mM}$ up to $10 \mathrm{mM}$. NPS 2390 (1 or 10 $u \mathrm{M}$ ) was pretreated for $2 \mathrm{~min}$ prior to increase extracellular calcium concentration. Arrow represents the time point of NPS 2390 treatment. Data was shown typical result from three independent experiments.

\section{Confocal microscopy for determining the localization of $\mathrm{CaSR}$ and $\mathrm{Cav}-1$}

Considering the experimental results of Figure 2, an immuno-cytochemical experiment using confocal microscope was performed to confirm the localization of CaSR and Cav-1 in the Saos-2 cells. Saos-2 cells were separately treated with the antibody for CaSR or Cav-1. This was followed by double staining with Texas Red (CaSR) and fluorescein isothiocyanate (Cav-1) antibodies. The green fluorescent Cav-1 stains were localized to the plasma membrane (Figure $3 A)$. The red fluorescent CaSR stain was also localized to the plasma membrane (Figure 3B). Image overlays showed that both CaSR and Cav-1 are co-localized to the plasma membrane (orange color) (Figure $3 \mathrm{C}$ ). To exclude any non-specific binding, the single effect of secondary antibodies was tested. No immuno-reactivity to the secondary antibodies was observed (Figure 3D and $3 E$ ).

\section{The effect of Cav-1 antisense ODN on CaSR- mediated $\left[\mathrm{Ca}^{2+}\right]_{i}$ changes}

To investigate the functional interaction of Cav-1 on CaSR function, the effect of Cav-1 on CaSR activity in Saos-2 cells was examined by employing an antisense ODN technique. The basal $\left[\mathrm{Ca}^{2+}\right]_{i}$ levels of scrambled or antisense ODN-treated cells were between 70 to $85 \mathrm{nM}$. When the cells were treated with Cav-1 scrambled ODN, the $\left[\mathrm{Ca}^{2+}\right]_{0}(5 \mathrm{mM})$-induced 
A

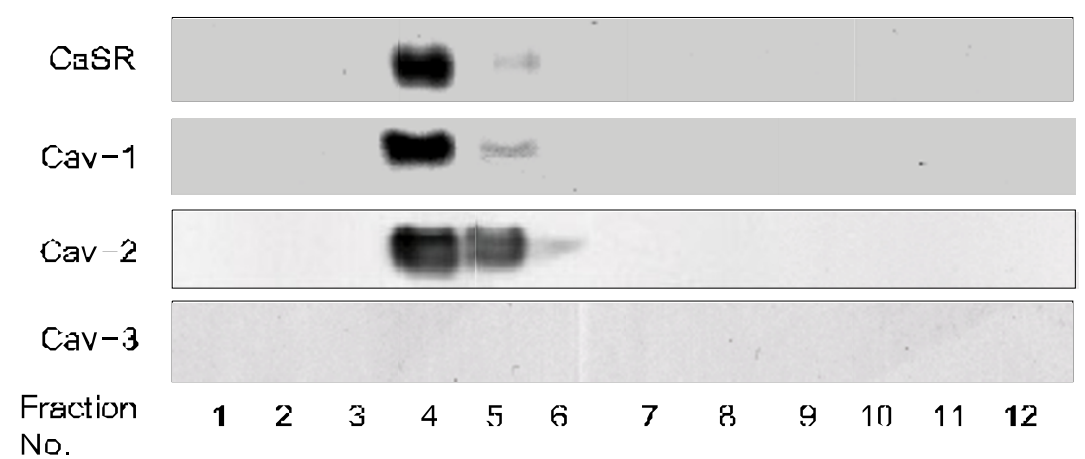

B
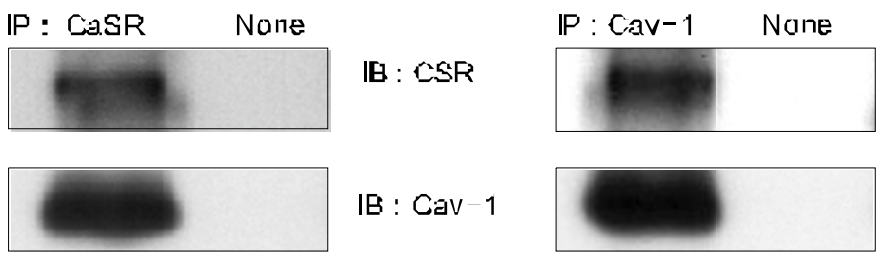

IB : Cav 1

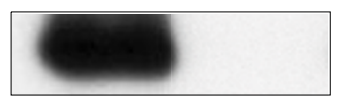

C

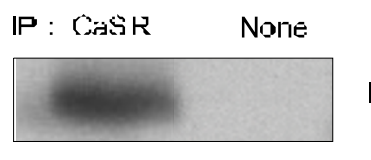

IB : $\operatorname{csR}$
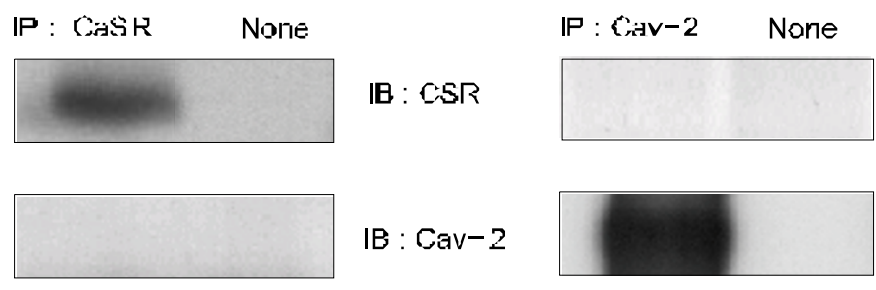

IB : Cav-2

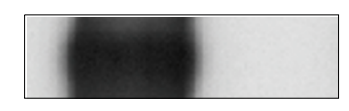

Figure 2. Co-localization of CaSR and caveolins in the caveolae-rich membrane fraction or co-precipitates by their antibodies. (A) The membrane fractions were isolated from Saos-2 cells using the sucrose density gradient centrifugations. Fractions obtained from Saos-2 cells were subjected to Western blot analysis with respective antibodies. B and C. The lysates of Saos-2 cells were immuno-precipitated initially with antibodies of CaSR or caveolins and the respective immuno-precipitated (IP) proteins $(15 \mu \mathrm{g})$ were loaded onto each lane of a $10 \%$ SDS-polyacrylamide gel. After separation of the proteins by electrophoresis and transferring the separated proteins to a membrane, the membrane was immuno-blotted (IB) using the indicated respective antibodies. (B) Cell lysates were immunoprecipitated initially CaSR or Cav-1 antibody. (C) Cell lysates were immuno-precipitated initially CaSR or Cav-2 antibody. net $\left[\mathrm{Ca}^{2+}\right]_{i}$ increment was slightly decreased, but this change was not significant $(113 \pm 12.2 \mathrm{nM}$ vs. 93.7 $\pm 26.1 \mathrm{nM}$ for the treated versus the untreated cells, respectively) (Figure 4A). In contrast, for the result using antisense ODN, the peak value of the $\left[\mathrm{Ca}^{2+}\right]_{\mathrm{i}}$ increment caused by $\left[\mathrm{Ca}^{2+}\right]_{0}(5 \mathrm{mM})$ was decreased by about $30 \%$ compared to that of the control (113 $\pm 12.2 \mathrm{nM}$ vs. $31.6 \pm 2.7 \mathrm{nM}$, respectively) (Figure 4B).

\section{Discussion}

The results obtained in the present study demonstrate that some portion of the CaSR protein in bone related cells (Saos-2) is bound to Cav-1, and the bound complex is localized in the caveolae-enriched plasma membrane fraction. Several lines of evidences we have provided in the current study support this conclusion: 1) RT-PCR and immuno-blot analysis indicated that CaSR, Cav-1 and Cav-2 are present in the Saos- 2 cells and they are all co-localized in the cav- eolae-enriched membrane fraction, 2) the results of cross-over immuno-precipitational experimentations show that the CaSR formed a bound complex with Cav-1, but not with Cav-2, and 3) the overlaid confocal microscopic immuno-cytochemistry images of CaSR and Cav-1 show that at least a portion of the CaSR is co-localized with Cav-1 in the plasma membrane.

Bone is an integral component of the $\mathrm{Ca}^{2+}$ homeostatic system. Functional and molecular biological data have demonstrated the existence of CaSR in bone. In osteoclasts, changes in $\left[\mathrm{Ca}^{2+}\right]_{0}$ alter the cells' morphology and inhibit bone reabsorption, while in osteoblasts, raising the $\left[\mathrm{Ca}^{2+}\right]_{0}$ induces a proliferative response (Brown, 1991). Recent works have indicated that the osteoblast-derived cell lines MC3T3-E1, UMR106, Saos-2 and MG-63 also express CaSR mRNA and protein, and that CaSR agonists stimulate chemotaxis and proliferation (Yamaguchi et al., 1998a; b; 2001). In spite of those reports, investigation on the relationship between CaSR and caveolins in osteoblast-derived cells can not be found. Thus, in this study, we first looked into the expressional patterns 

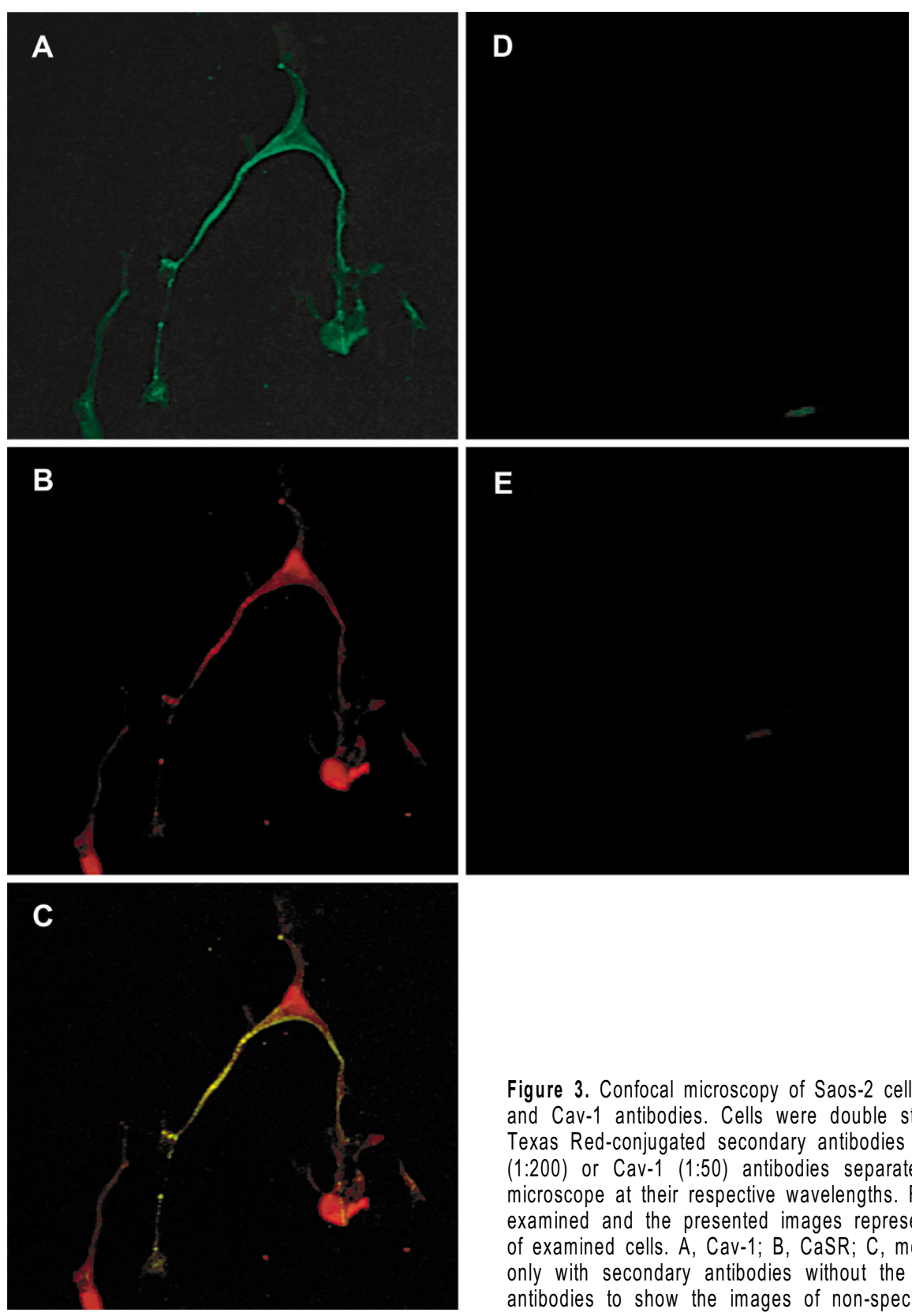

Figure 3. Confocal microscopy of Saos-2 cells immuno-cytochemically stained with CaSR and Cav-1 antibodies. Cells were double stained with fluorescein isothiocyanate- and Texas Red-conjugated secondary antibodies after an initial treatment with either CaSR $(1: 200)$ or Cav-1 (1:50) antibodies separately and then examined under a confocal microscope at their respective wavelengths. For each experiment, a least 50 cells were examined and the presented images represent typical staining pattern for the majority of examined cells. A, Cav-1; B, CaSR; C, merged image of A and B; D and E, stained only with secondary antibodies without the prior treatment of either CaSR or Cav-1 antibodies to show the images of non-specific bindings.

of CaSR and caveolins in osteoblast-derived cells, the Saos- 2 cell line. As shown in Figure $1 \mathrm{C}$, the $\left[\mathrm{Ca}^{2+}\right]_{0}-$ stimulated $\left[\mathrm{Ca}^{2+}\right]_{i}$ was increased by $\left[\mathrm{Ca}^{2+}\right]_{0}$ in a dosedependent manner and this increment was attenuated by NPS 2390 treatment in a concentration-dependent manner (Van Wagenen et al., 2000). In addition, RT-PCR and Western blotting analyses showed that CaSR, Cav-1 and Cav-2 mRNA and their proteins were expressed in Saos-2 cells, while expression of Cav-3 was not observed (Figure 1). These results showed that Saos-2 cells expressed CaSR and they are a useful cell line in characterization for CaSR.

Caveolae were originally described in endothelial cells as the flask-shaped vesicular invaginations in the plasma membrane, and they are rich with cholesterol, glycosphingolipids and sphingomyelin, and they are not solubilized by detergents. Membrane receptor associated signaling molecules like the G-protein, Src family kinases, endothelial nitric oxide synthase and Ha-Ras are known to be anchored to caveolae via the caveolins, and the caveolae have been implicated to function as the portals for signal transduction and for vesicular transport processes (Lisanti et al., 1994; Couet et al., 1997). In the bone, osteoblast cells play an important role in bone remodeling. They have many functional proteins related to bone metabolism 

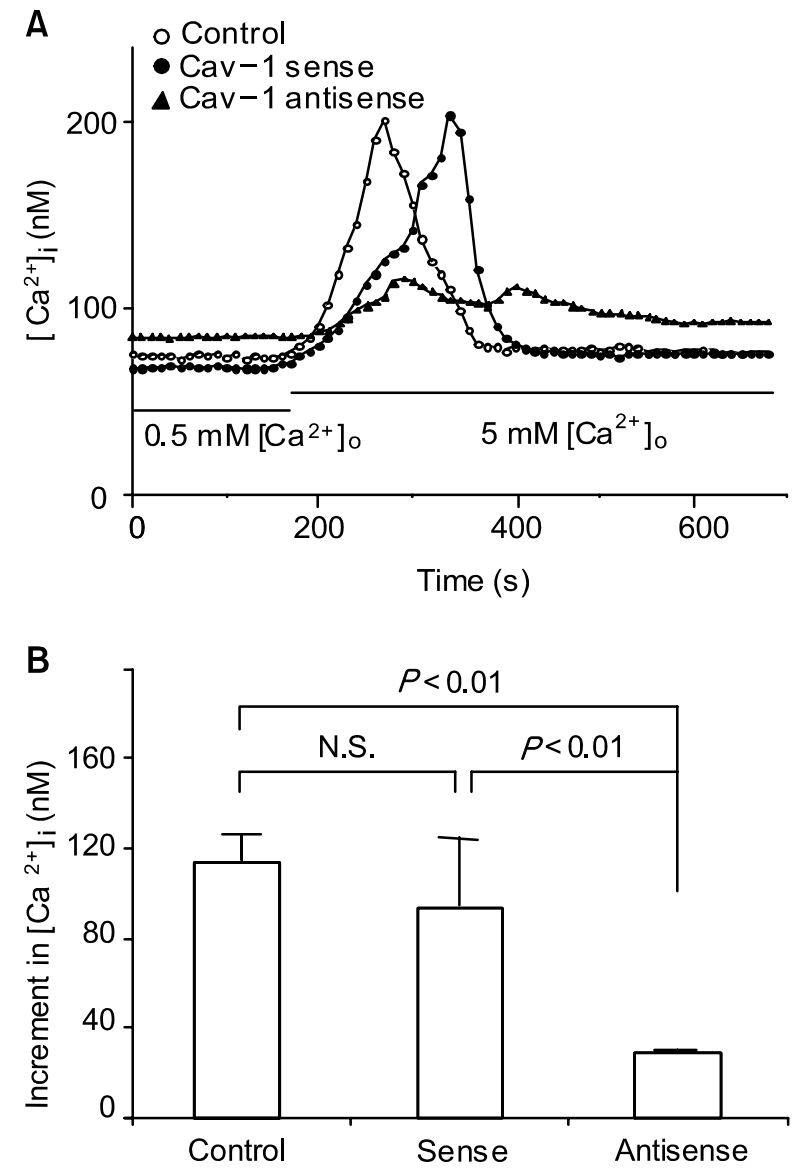

Figure 4. Effect of Cav-1 antisense ODN on $\left[\mathrm{Ca}^{2+}\right]_{0}$-mediated $\left[\mathrm{Ca}^{2+}\right]_{\text {i }}$ by CaSR in Saos-2 cells. Saos-2 cells grown on cover slips were introduced scrambled and antisense ODN $(1 \mu \mathrm{M})$ for $24 \mathrm{~h}$ by Lipofect amine. The cells were then loaded with fura-2, and observed by fluorescent digital imaging. Extracelluar calcium concentration was changed from $0.5 \mathrm{mM}$ to $5 \mathrm{mM}$ after being stable in basal level of $\left[\mathrm{Ca}^{2+}\right]_{\text {. }}$. A. Typical signaling of $\left[\mathrm{Ca}^{2+}\right]_{i}$ increment stimulated by $\left[\mathrm{Ca}^{2+}\right]_{0}$ $(5 \mathrm{mM})$ in non-treated, scrambled or antisense ODNs treated Saos-2 cells. B. The effect of scrambled or antisense ODNs on $\left[\mathrm{Ca}^{2+}\right]$ increase by $\left[\mathrm{Ca}^{2+}\right]_{0}$. The values of bar graphs were presented by mean \pm standard errors of 11-15 cells/test of independent 3 experiments. ANOVA test were employed for statistical difference among groups.

(Lisanti et al., 1994; Hikiji et al., 2004; Kondo and Togari, 2004; Tanimoto et al., 2004; Urano et al., 2004). In this connection, osteoblast cells are known to contain many receptors and membrane associated signal molecules like the G-protein, protein kinase $C$ and protein kinase $A$, among others. These membrane associated signaling molecules are known to contain a common amino acid sequence motif (i.e., $\phi X \phi X X X X \phi$ or $\phi X X X X \phi X X \phi$, in which $\phi$ designates aromatic amino acids like Trp $(W)$, Phe $(F)$ or Tyr $(Y)$, and $X$ can be any amino acids) that recognizes the scaffolding domains that are present in the caveolins. Generally, the functions of these signal molecules contained in caveolae are known to be inhibited upon binding to the caveolins via the scaffolding domains.
In a recent study, we have reported the up-regulatory effect of caveolin on the sodium-calcium exchanger 1 (Cha et al., 2005). As shown in Figure 5, a scan of the CaSR primary amino acid sequence indicated that two potential caveolin-binding motifs are located at amino acids 629-637 (FVLGYFIKF) and 801-809 (FNEAKFITF). They are located at near the cytoplasmic face of the plasma membrane. These binding motifs are also well conserved those in rat and mouse CaSR.

Caveolin also receives effect of phospholipase $C$ (PLC). Among the PLC isoforms, PLC $\gamma 1$ signaling occurs in caveolae (Jang et al., 2001). CaSR is also related with PLC. Chang and co-workers (Chang et al., 2000) have reported that second and third intracellular loops of the CaSR is coupled with PLC. CaSR belongs to the type III family of G-proteincoupled receptors, which comprises the metabotropic glutamate receptor and putative vomeronasal organ receptors (Brown et al., 1993). When scanned the amino-acid sequences consisting of third intracellular loop of CaSR and mGluR1-8, high level of amino-acid homology (67 to $85 \%$ ) was appeared. The cavolinbinding motif (801-809) was just fitted to this site. This fact strongly suggests that this site is Cav-1 binding motif of CaSR and probably CaSR function is regulated via PLC signaling pathway.

As shown in Figure 2A, even though CaSR, Cav1 and Cav-2 were co-localized in same caveolaeenriched fraction, Cav-2 was not directly bound with CaSR (Figure 2C). This result was also confirmed by confocal microscopy (data not shown). In the case of Cav-1, similar results were also obtained from cultured bovine parathyroid cells, human parathyroid adenoma and CaSR-transfected HEK 293 cells (Kifor et al.,1998; 2003a; b). The interaction between CaSR and Cav-3 is at present unknown. Especially, future study on CaSR's interaction with caveolin-3, which is known to be muscle specific, will be necessary, because the calcium ion is very important in performing the contractile function of skeletal muscle and smooth muscle.

In order to demonstrate the relationship between $\mathrm{CaSR}$ and $\mathrm{Cav}-1$, we investigated functional $\left[\mathrm{Ca}^{2+}\right]_{\mathrm{i}}$ increments stimulated by $\left[\mathrm{Ca}^{2+}\right]_{0}$ by using human Cav-1 scrambled or antisense ODNs in Saos-2 cells. Although there were no detectable changes of the CaSR mRNA or protein expression with treatments using scrambled or antisense ODNs (data not shown), the increase of $\left[\mathrm{Ca}^{2+}\right]_{i}$ was significantly inhibited by treatment with antisense ODN, but not with scrambled ODN. Mice lacking the Cav-1 gene by excision of the exon-3, which encodes the transmembrane domain, show the complete absence of caveolae in all observed organs, lung, adipose tissue, diaphragm, kidney and heart (Drab et al., 2001). It has been reported that the Cav-2 transcript was still present, but the protein could not be detected. Because Cav-1 and Cav-2 form hetero-oligomers (Scheiffele et al., 1998), Cav-2 may degraded in the absence of Cav- 1 . When the role of Cav-1 in knockout mice was investigated, the calcium-dependent contractile response of arteries 


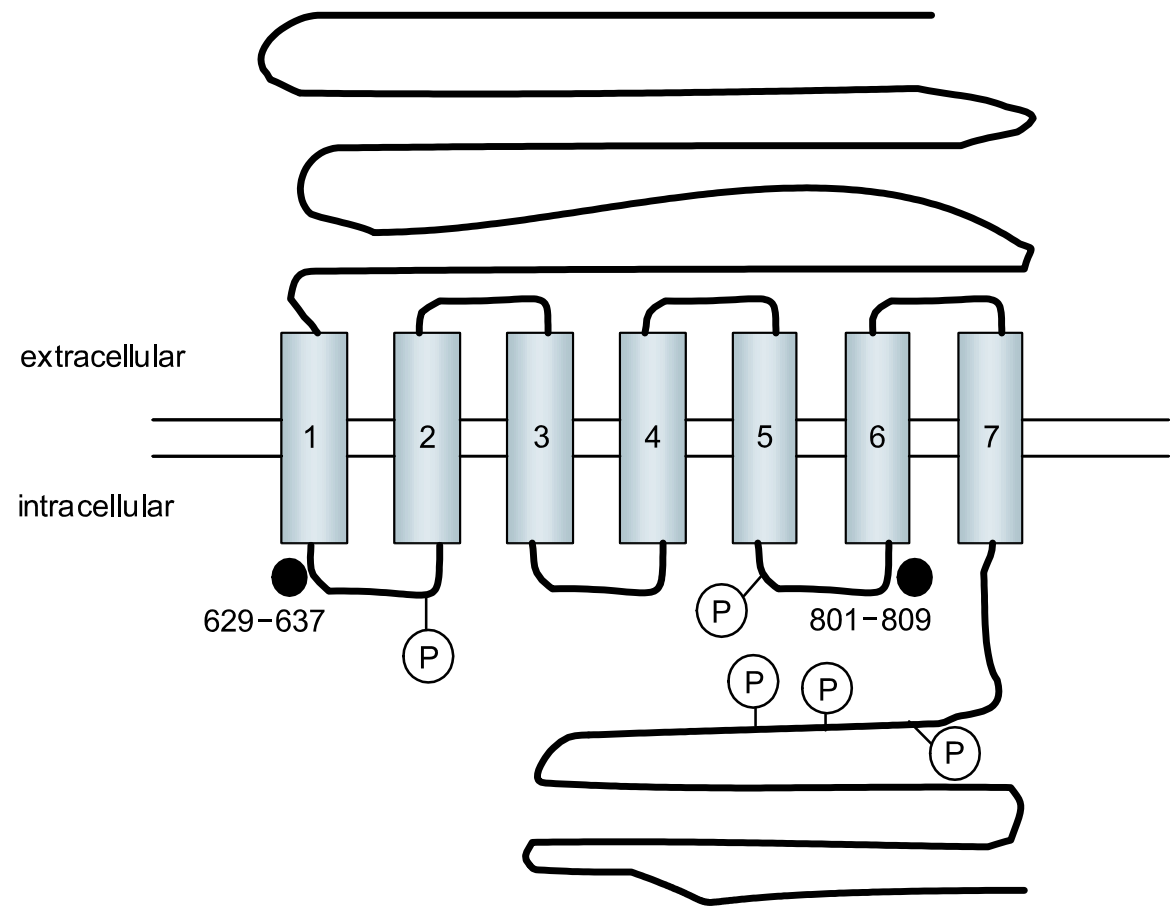

Figure 5. Predicted location of CaSR caveolin-binding motifs. The hydropathy plot model of CaSR is based upon topological analysis. Transmembrane regions are represented by shaded cylinders and extramembranal loops are black lines. Closed circles designate the approximate location of the CaSR caveolin-binding motifs. (P) designates the protein kinase $\mathrm{C}$ site. Numbers shows amino acids for caveolin-binding motifs.

to angotensin II, endothelin-1 and phorbol ester was attenuated (Escriche et al., 2003). This result suggests Cav-1 may be concerned with physiological phenomena that are related to calcium homeostasis in the body. Considering our experimental result using antisense ODN, Cav-1 bound with CaSR up-regulates the function of CaSR.

In speculation, another possible regulatory mechanism of caveolin for the function of receptor related with caveolin was the internalization of the caveolinanchored receptor proteins (Okamoto et al., 2000; Escriche et al., 2003). There are many reports on receptor internalization by the activation of protein kinase C (PKC) (Mundell et al., 2003; Montiel et al., 2004; Saito et al., 2004). The tyrosine or serine residue of Cav-1 was also phosphorylated down stream of the signal transduction pathway of ligand-stimulated receptor or that induced by stress (Maggi et al., 2002; Sanguinetti et al., 2003). It is interesting that the likely candidates for the caveolin-binding motif in CaSR are located closely near the PKC site (Figure 5). Even though in speculation, the relationship between PKC and caveolin will be concerned for functional regulation of CaSR. The study on internalization of CaSR by caveolin-I phosphorylation that was followed by autocrine or paracrine stimulation by its ligand will be necessary.

In conclusion, we report here on the protein-protein interaction of CaSR and Cav-1. CaSR and Cav-1 are co-localized in the caveolae of the plasma membrane and they form a protein-protein complex. The $\left[\mathrm{Ca}^{2+}\right]_{0}$ stimulated $\left[\mathrm{Ca}^{2+}\right]_{\mathrm{i}}$ increment is up-regulated by Cav-1 under normal physiological conditions. It is necessary to investigate the regulatory mechanism of caveoin-1 on caveolin phosphorylation and the internalization or recycling of caveolae, and so forth. Informations from this current study might help give us some important clues on the pathological and/or physiological processes of bone remodeling or on the CaSR related disorders in the body.

\section{Acknowledgement}

This study was supported by a grant of the Korea Health 21 R\&D Project. Ministry of Health \& Welfare, R.O.K (03-PJ10-PG13-GD01-0002).

\section{References}

Adebanjo OA, Shankar VS, Pazianas M, Zaidi A, Simon B, Huang $C L$, Zaidi M. Modulation of the osteoclast $\mathrm{Ca}^{2+}$ receptor by extracellular protons: possible linkage between $\mathrm{Ca}^{2+}$ sensing and extracellular acidification. Biochem Biophys Res Commun 1994;199:742-7

Brown EM. Extracellular $\mathrm{Ca}^{2+}$-sensing, regulation of parathyroid cell function and role of $\mathrm{Ca}^{2+}$ and other ions as extracellular (first) messengers. Physiol Rev 1991;71:371-411

Brown EM, Gamba G, Riccardi D, Lombardi M, Butters R, Kifor O, Sun A, Hediger MA, Lytton J, Hebert SC. Cloning and characterization of an extracellular $\left(\mathrm{Ca}^{2+}\right)$ sensing receptor from bovine parathyroid gland. Nature 1993;366:57580

Cha SH, Hahn TW, Sekine T, Lee KH, Endou H. Purinoceptor-mediated calcium mobilization and cellular proliferation in cultured bovine corneal endothelial cells. Jpn J Pharmacol 2000;82:181-7 
Cha SH, Jung NH, Kim BR, Kim HW, Kwak JO. Evidence for cyclooxygenase-1 association with caveolin-1 and -2 in cultured human embryonic kidney (HEK 293) cells. IUBMB Life 2004;56:221-7

Cha SH, Shin SY, Jung SY, Kim YT, Park YJ, Kwak JO, Kim HW, Suh CK. Evidence for $\mathrm{Na}^{+} / \mathrm{Ca}^{2+}$ exchanger 1 Association with caveolin-1 and -2 in $\mathrm{C} 6$ glioma cells. IUBMB Life 2004;56:621-7

Chang W, Chen TH, Pratt S, Shoback D. Amino acids in the second and third intracellular loops of the parathyroid $\mathrm{Ca}^{2+}$-sensing receptor mediate efficient coupling to phospholipase C. J Biol Chem 2000;275:19955-63

Couet J, Li S, Okamoto T, Ikezu T, Lisanti MP. Identification of peptide and protein ligands for the caveolin-scaffolding domain. Implications for the interaction of caveolin with caveolae-associated proteins. J Biol Chem 1997;272:6525-33

Drab M, Verkade P, Elger M, Kasper M, Lohn M, Lauterbach B, Menne J, Lindschau C, Mende F, Luft FC, Schedl A, Haller H, Kurzchalia TV. Loss of caveolae, vascular dysfunction, and pulmonary defects in caveolin-1 gene-disrupted mice. Science 2001;293:2449-52

Escriche M, Burgueno J, Ciruela F, Canela El, Mallol J, Enrich C, Lluis C, Franco R. Ligand-induced caveolae-mediated internalization of $\mathrm{A} 1$ adenosine receptors: morphological evidence of endosomal sorting and receptor recycling. Exp Cell Res 2003;285:72-90

Garcia-Cardena G, Fan R, Stern DF, Liu J, Sessa WC. Endothelial nitric oxide synthase is regulated by tyrosine phosphorylation and interacts with caveolin-1. J Biol Chem 1996; 271:27237-40

Griffoni C, Spisni E, Santi S, Riccio M, Guarnieri T, Tomasi V. Knockdown of caveolin-1 by antisense oligodeoxynucleotides impairs angiogenesis in vitro and in vivo. Biochem Biophys Res Commun 2000;276:756-61

Hikiji H, Ishii S, Shindou H, Takato T, Shimizu T. Absence of platelet-activating factor receptor protects mice from osteoporosis following ovariectomy. J Clin Invest 2004;114:85-93

Jang I, Kim JH, Lee BD, Bae SS, Park MH, Suh P, Ryu $\mathrm{SH}$. Localization of phospholipase $\mathrm{C}$-g1 signaling in caveolae: importance in EGF-induced phosphoinositide hydrolysis but not in tyrosine phosphorylation. FEBS Lett 2001;491:4-8

Kameda T, Mano H, Yamada Y, Takai H, Amizuka N, Kobori $\mathrm{M}$, Izumi N, Kawashima $\mathrm{H}$, Ozawa $\mathrm{H}$, Ikeda K, Kameda A, Hakeda $Y$, Kumegawa $M$. Calcium-sensing receptor in mature osteoclasts, which are bone resorbing cells. Biochem Biophys Res Commun 1998;245:419-22

Kifor O, Diaz R, Butters R, Kifor I, Brown EM. The calciumsensing receptor is localized in caveolin-rich plasma membrane domains of bovine parathyroid cells. J Biol Chem 1998;273:21708-13

Kifor O, Kifor I, Moore FD Jr, Butters RR Jr, Brown EM. $\mathrm{m}$-Calpain colocalizes with the calcium-sensing receptor $(\mathrm{CaR})$ in caveolae in parathyroid cells and participates in degradation of the CaR. J Biol Chem 2003a;278:31167-76

Kifor O, Kifor I, Moore FD Jr, Butters RR Jr, Cantor T, Gao $P$, Brown EM. Decreased expression of caveolin-1 and altered regulation of mitogen-activated protein kinase in cul- tured bovine parathyroid cells and human parathyroid adenomas. J Clin Endocrinol Metab 2003b;88:4455-64

Kondo A, Togari A. Activation of osteoblastic functions by a mediator of pain, bradykinin. Biochem Pharmacol 2004; 68:1423-31

Kurzchalia TV, Parton RG. Membrane microdomains and caveolae. Curr Opin Cell Biol 1999;11:424-31

Lee H, Woodman SE, Engelman JA, Volonte D, Galbiati F. Palmitoylation of caveolin-1 at a single site (Cys-156) controls its coupling to the c-Src tyrosine kinase: targeting of dually acylated molecules (GPI-linked, transmembrane, or cytoplasmic) to caveolae effectively uncouples c-Src and caveolin-1 (TYR-14). J Biol Chem 2001;276:35150-8

Li S, Okamoto T, Chun M, Sargicomo M, Casanova JE. Evidence for a regulated interaction between heterotrimeric G proteins and caveolin. J Biol Chem 1995;270:15693-701

Liou JY, Deng WG, Gilroy DW, Shyue SK, Wu KK. Colocalization and interaction of cyclooxygenase-2 with caveolin-1 in human fibroblasts. J Biol Chem 2001;276:34975-82

Lisanti MP, Scherer PE, Tang Z, Sargiacomo M. Caveolae, caveolin and caveolin-rich membrane domains: a signaling hypothesis. Trends Cell Biol 1994;4:231-5

Maggi D, Biedi C, Segat D, Barbero D, Panetta D, Cordera R. IGF-I induces caveolin 1 tyrosine phosphorylation and translocation in the lipid rafts. Biochem Biophys Res Commun 2002;295:1085-9

Montiel M, Quesada J, Jimenez E. Activation of second messenger-dependent protein kinases induces muscarinic acetylcholine receptor desensitization in rat thyroid epithelial cells. Mol Cell Endocrinol 2004;223:35-41

Mundell SJ, Pula G, Carswell K, Roberts PJ, Kelly E. Agonist-induced internalization of metabotropic glutamate receptor 1A: structural determinants for protein kinase $C$ - and $\mathrm{G}$ protein-coupled receptor kinase-mediated internalization. $\mathrm{J}$ Neurochem 2003;84:294-304

Okamoto T, Schlegel A, Scherer PE, Lisanti MP. Caveolins, a family of scaffolding proteins for organizing "pre-assembled signaling complexes" at the plasma membrane. J Biol Chem 1998;273:5419-22

Okamoto $\mathrm{Y}$, Ninomiya H, Miwa S, Masaki T. Cholesterol oxidation switches the internalization pathway of endothelin receptor type A from caveolae to clathrin-coated pits in Chinese hamster ovary cells. J Biol Chem 2000;275:6439-46

Rasheed H, Saeed SA. Involvement of thromboxane A2 and tyrosine kinase in the synergistic interaction of platelet activating factor and calcium ionophore A23187 in human platelet aggregation. Exp Mol Med 2004;36:220-5

Saito Y, Tetsuka M, Li Y, Kurose H, Maruyama K. Properties of rat melanin-concentrating hormone receptor 1 internalization. Peptides 2004;25:1597-604

Sanguinetti AR, Cao H, Mastick CC. Fyn is required for oxidative- and hyperosmotic-stress-induced tyrosine phosphorylation of caveolin-1. Biochem J 2003;376:159-68

Scheiffele $P$, Verkade $P$, Fra AM, Virta $H$, Simons $K$, Ikonen E. Caveolin-1 and -2 in the exocytic pathway of MDCK cells. J Cell Biol 1998;140:795-806 
Shin MM, Kim YH, Kim SN, Kim GS, Baek JH. High extracellular $\mathrm{Ca}^{2+}$ alone stimulates osteoclast formation but inhibits in the presence of other osteoclastogenic factors. Exp Mol Med 2003;35:167-74

Tanimoto Y, Yokozeki M, Hiura K, Matsumoto K, Nakanishi $\mathrm{H}$, Matsumoto T, Marie PJ, Moriyama K. A soluble form of fibroblast growth factor receptor 2 (FGFR2) with S252W mutation acts as an efficient inhibitor for the enhanced osteoblastic differentiation caused by FGFR2 activation in Apert syndrome. J Biol Chem 2004;279:45926-34

Urano T, Shiraki M, Ezura Y, Fujita M, Sekine E, Hoshino $\mathrm{S}$, Hosoi T, Orimo H, Emi M, Ouchi Y, Inoue S. Association of a single-nucleotide polymorphism in low-density lipoprotein receptor-related protein 5 gene with bone mineral density. $J$ Bone Miner Metab 2004;22:341-5

Van Wagenen BC, Smith DL, Artman LD, Hammerland LG, Heaton WL, Hung BCP, Krapcho KJ, Levinthal C, Logan MA, Mueller AM, Moe ST, Sheehan SMK, Storjohann L, Trovato R, Walton RJ, Stormann TM. Structure-activity relationship studies of NPS 2390: A potent and selective group 1 metabotropic glutamate receptor antagonist. Soc Neurosci 2000; Abstr. 618.3

Yamaguchi T, Chattopadhyay N, Kifor O, Butters RR Jr, Sugimoto T, Brown EM. Mouse osteoblastic cell line (MC3T3-
E1) expresses extracellular calcium $\left(\mathrm{Ca}^{2+} 0\right)$-sensing receptor and its agonists stimulate chemotaxis and proliferation of MC3T3-E1 cells. J Bone Miner Res 1998a;13:1530-8

Yamaguchi T, Kifor O, Chattopadhyay N, Brown EM. Expression of extracellular calcium $\left(\mathrm{Ca}^{2+} \mathrm{O}\right)$-sensing receptor in the clonal osteoblast-like cell lines, UMR-106 and SAOS-2. Biochem Biophys Res Commun 1998b;243:753-7

Yamaguchi T, Chattopadhyay N, Kifor O, Ye C, Vassilev PM, Sanders JL, Brown EM. Expression of extracellular calciumsensing receptor in human osteoblastic MG-63 cell line. Am J Physiol 2001;280:C382-93

Zaidi M, Datta HK, Patchell A, Moonga B, Maclntyre I. 'Calcium-activated' intracellular calcium elevation: a novel mechanism of osteoclast regulation. Biochem Biophys Res Commun 1989;163:1461-5

Zaidi M, Kerby J, Huang CL, Alam T, Rathod H, Chambers TJ, Moonga BS. Divalent cations mimic the inhibitory effect of extracellular ionised calcium on bone resorption by isolated rat osteoclasts: further evidence for a "calcium receptor". J Cell Physiol 1991;149:422-7

Zaidi M, Alam AS, Huang CL, Pazianas M, Bax CM, Bax $\mathrm{BE}$, Moonga BS, Bevis PJ, Shankar VS. Extracellular $\mathrm{Ca}^{2+}$ sensing by the osteoclast. Cell Calcium 1993;14:271-7 